\title{
A strategic approach to [6,6]-bicyclic lactones: application towards the CD fragment of DH $\beta E$
}

\author{
Tue Heesgaard Jepsen ${ }^{\ddagger}$, Emil Glibstrup ${ }^{\ddagger}$, François Crestey, Anders A. Jensen \\ and Jesper Langgaard Kristensen ${ }^{*}$
}

\author{
Full Research Paper \\ Address: \\ Department of Drug Design and Pharmacology, Faculty of Health and \\ Medical Sciences, University of Copenhagen, Universitetsparken 2, \\ 2100 Copenhagen, Denmark \\ Email: \\ Jesper Langgaard Kristensen* - jesper.kristensen@sund.ku.dk \\ * Corresponding author $\ddagger$ Equal contributors \\ Keywords: \\ DhßE; Mizoroki-Heck cross-coupling reaction; 6r-electrocyclization; \\ [6,6]-bicyclic lactone; vinyl halide
}

Beilstein J. Org. Chem. 2017, 13, 988-994.

doi:10.3762/bjoc. 13.98

Received: 02 March 2017

Accepted: 11 May 2017

Published: 22 May 2017

Associate Editor: D. J. Dixon

(c) 2017 Jepsen et al.; licensee Beilstein-Institut.

License and terms: see end of document.

\begin{abstract}
We report an effective synthetic protocol to access [6,6]-bicyclic lactone moieties through a regio- and stereoselective intramolecular Mizoroki-Heck cross-coupling reaction followed by a $6 \pi$-electrocyclization. This method enabled the first synthesis of the elusive CD fragment of the Erythrina alkaloid DH $\beta$ E. Preliminary pharmacological evaluations support the notion that the key pharmacophores of $\mathrm{DH} \beta \mathrm{E}$ are located in the A and B rings.
\end{abstract}

\section{Introduction}

The neuronal nicotinic acetylcholine receptors (nAChRs) have been extensively investigated as potential drug targets for a diverse array of central nervous system (CNS) related medical conditions such as Alzheimer's and Parkinson's disease, depression, ADHD, pain relief, nicotine addiction and drug abuse [1] Dihydro- $\beta$-erythroidine (DH $\beta E$ ) is a member of the family of tetracyclic Erythrina alkaloids which were isolated from Erythrina species in the end of the 19th century; the majority of this family possesses neuromuscular blocking effects [2]. DH $\beta E$ is one of the most potent $\mathrm{nAChR}$ antagonists of this class and displays prominent selectivity for the $\alpha 4 \beta 2$ subtype ( $K_{\mathrm{i}}=0.82 \mu \mathrm{M}$ in a $\left[{ }^{3} \mathrm{H}\right]$ epibatidine binding assay) [3]. So far, $\mathrm{DH} \beta \mathrm{E}$ represents one of the simplest reference competitive antagonists for the $\alpha 4 \beta 2 \mathrm{nAChR}$ subtype. Although its chemical structure has been known for several decades [4,5], no comprehensive SAR study of DH $\beta E$ can be found in the literature, except from our previous deconstruction approach [3] and a few degradation studies $[6,7]$.

Balle and co-workers recently published an X-ray structure of the acetylcholine binding protein (AChBP) in complex with $\mathrm{DH} \beta \mathrm{E}[8]$ and based on this structure, two key pharmacophores of $\mathrm{DH} \beta \mathrm{E}$ were proposed as shown in Figure 1a: the methoxy group in the A ring which interacts via hydrogen bonding with a tightly bound water molecule in the protein and the protonated amine which forms hydrogen bonds directly with the backbone 
a) DHBE pharmacophore models
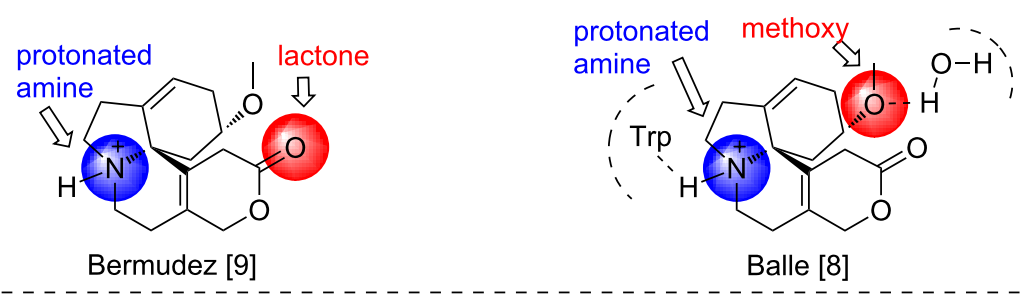

b) $D H \beta E$ deconstruction

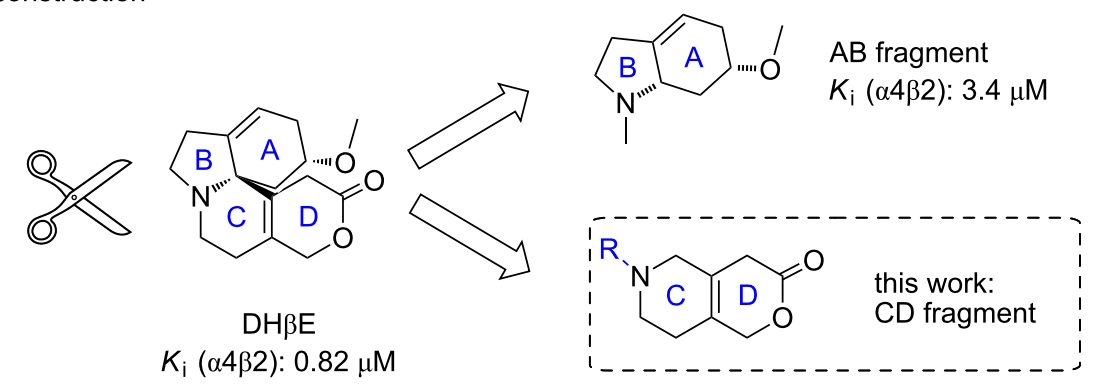

Figure 1: $\mathrm{DH} \beta E$ and related structures. The $K_{\mathrm{i}}$ values of the compounds at the rat $\alpha 4 \beta 2 \mathrm{nAChR}$ subtype determined in a $\left.{ }^{3} \mathrm{H}\right] \mathrm{cytisine}$ binding assay are given [3].

of the protein. Thus, this structure indicates that the key pharmacophores are located in the A ring and the $\mathrm{B}-\mathrm{C}$ ring, which contrasts a mutational-computational study by Bermudez and co-workers suggesting that the lactone carbonyl is a hydrogen bond acceptor and hence locating the key pharmacophores in the $\mathrm{C}$ and $\mathrm{D}$ rings [9]. In order to weigh these hypotheses against one another, we have recently published a SAR on the deconstructed $\mathrm{AB}$ fragments of $\mathrm{DH} \beta \mathrm{E}$ [3]; while reducing the molecular size and complexity considerably, we were able to retain the affinity, $\alpha 4 \beta 2$-subtype selectivity and competitive antagonist properties in the direct AB-analogue of DH $\beta E$ (see Figure $1 b$ ). On the other hand, we have previously deconstructed a selection of aromatic erythrinanes, and interestingly the SAR showed CD fragments with retained affinity, subtype specificity, and competitive antagonist property relative to the parent natural product [10]. Inspired by these results, we embarked on the synthesis of the CD fragment of DH $\beta E$.

Previously, the aromatic CD fragments were straightforwardly synthesized due to the advantageous reactivity of the aromatic D ring [10]. However, the syntheses of the lactonic Erythrina alkaloids are more complex $[11,12]$ as illustrated by more than 150 total syntheses reported for aromatic erythrinanes [2] whereas only four total syntheses of lactonic erythrinanes have been published so far [13-16]. Hence, for the DHßE-based CD fragments, we faced a significantly more challenging synthesis due to the complex nature of the $[6,6]$-bicyclic lactone moiety for which synthetic procedures are extremely scarce. Herein, we wish to provide different strategies used to synthesize the CD fragment of $\mathrm{DH} \beta \mathrm{E}$ as a general and simple method for the construction of [6,6]-bicyclic lactones which includes a stereoselective synthesis of vinyl halides, a regio- and stereoselective intramolecular Mizoroki-Heck cross-coupling reaction and a $6 \pi$-electrocyclization as key steps.

\section{Results and Discussion First strategy with $\mathrm{Ts}$ and $\mathrm{Cbz}$ protecting groups}

As depicted in Scheme 1, our first strategy featured a late stage installation of the lactonic $\mathrm{D}$ ring by a $6 \pi$-electrocyclization and formation of the $\mathrm{C}$ ring by an intramolecular Mizoroki-Heck cross-coupling reaction from a $Z$-configured olefin which would be crucial to the stereochemical outcome of the Heck cyclization event. We envisioned a $Z$-stereoselective synthesis of a vinyl halide [17] which should secure the desired $E$-stereochemistry for the Mizoroki-Heck coupling. We were aware that we would perhaps face a greater challenge in terms of generating the desired 6-membered exocyclic product rather than the undesired 7-membered endocyclic product [18]. Starting from commercially available propargylamine, tosylated compound $\mathbf{1}$ was prepared in $88 \%$ yield followed by its alkylation using mesylated homoallylic alcohol to provide $\mathbf{2}$ in $93 \%$ yield. The incorporation of the ester functionality proved to be more troublesome than anticipated based on literature precedence [19]. After extensive optimization, it was found that deprotonation of the terminal alkyne with $n$-BuLi and subsequent quenching with 


\section{Retrosynthesis:}<smiles>C=C(Br)CCN(CCOC(=O)OC)C(=O)OC</smiles>

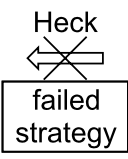

PG.<smiles>[R]OC(=O)C=C1CNCCC1=C</smiles>

$\underset{\text { 1st }}{\stackrel{\text { Heck }}{\rightleftarrows}}$

(E)-6-exo<smiles>C=CCCN(CC(=O)OCC)CC(C)=[18O]</smiles>

$\sqrt{1}$

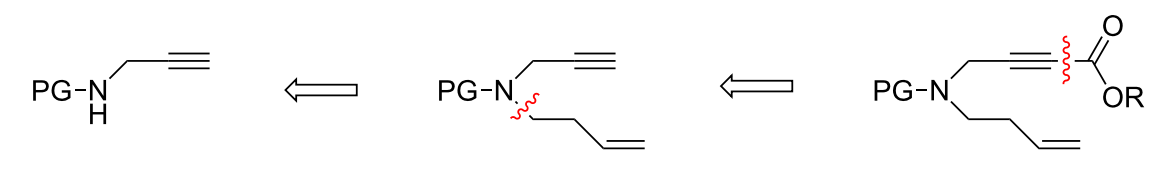

$\equiv \mathrm{NH}_{2}$
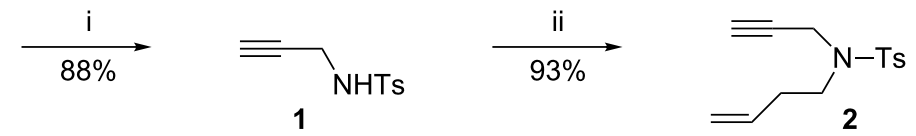

2

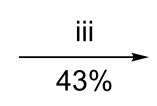

(Z) -4
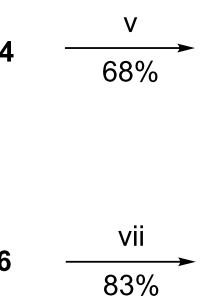<smiles>CCCCN([13CH3])CC#CC(=O)OCC</smiles>

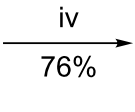<smiles>[3H]N1CCC(=C)/C(=C\C(=O)OCC)C1</smiles>

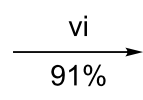

$(E)-(6-\mathrm{exo})-5$<smiles>[3H]C1=C2COC(=O)CC2=C(N([3H])[AsH])C1</smiles><smiles>CCCC</smiles><smiles>CCCC1CCNCC1=C1CCC(=O)OC1</smiles>

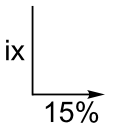<smiles>CCOC(=O)/C=C(\I)CN([As])CC/C=C\[Te]</smiles><smiles>C=C1CCN([As])C/C1=C/C(=O)O</smiles>

6

Scheme 1: First strategy towards the $\mathrm{CD}$ fragment (Ts-strategy). i) $\mathrm{TsCl}, \mathrm{TEA}, \mathrm{DCM}, 0^{\circ} \mathrm{C}$. ii) NaH, DMF, $0{ }^{\circ} \mathrm{C}$, then 3-buten-1-yl methanesulfonate, $100{ }^{\circ} \mathrm{C}$. iii) $n$-BuLi, $\mathrm{ClCO}_{2} \mathrm{Et}, \mathrm{THF},-78^{\circ} \mathrm{C}$. iv) Lil, $\mathrm{AcOH}, 70^{\circ} \mathrm{C}$. v) $\mathrm{PdCl}_{2}\left(\mathrm{PPh}_{3}\right)_{2}, \mathrm{Ag}_{2} \mathrm{CO}_{3}$, THF, rt. vi) $\mathrm{LiOH}, \mathrm{H}_{2} \mathrm{O}$, THF, rt. vii) BHT (cat.), $\mathrm{PhMe}$, reflux. viii) $\mathrm{Sml}_{2}$. ix) Sodium naphthalenide, DME, $-78{ }^{\circ} \mathrm{C}$, then $\mathrm{Boc}_{2} \mathrm{O}$, rt. $\mathrm{x}$ ) TFA, DCM, rt. For more details regarding the failed strategy, see Supporting Information File 1.

ethyl chloroformate provided the desired ester 3 in $43 \%$ yield. The subsequent stereoselective addition of lithium iodide [17] provided the $Z$-vinyl iodide 4 in $76 \%$ yield with no trace of the undesired $E$-isomer.

After extensive screening (see Supporting Information File 1 for more details), the key Mizoroki-Heck cross-coupling reaction was performed at room temperature providing the desired $(E)$ (6-exo)-5 product in $68 \%$ yield using $\mathrm{PdCl}_{2}\left(\mathrm{PPh}_{3}\right)_{2}$ as catalyst and $\mathrm{Ag}_{2} \mathrm{CO}_{3}$ as base in THF. Hydrolysis of the ester $(E)-(6-$ exo)-5 with $\mathrm{LiOH}$ was achieved in $91 \%$ yield to furnish carboxylic acid $\mathbf{6}$. The subsequent $6 \pi$-electrocyclization performed in refluxing toluene in the presence of a catalytic amount of 2,6-di-tert-butyl-4-methylphenol (BHT) led to lactone 7 in $83 \%$ yield. The removal of the Ts-protecting group was initially attempted with $\mathrm{SmI}_{2}$ but unfortunately this reaction proceeded without a trace of the desired lactone 9. Recently Szostak et al. have shown that 6-membered lactones undergo reduction with $\mathrm{SmI}_{2}[20]$ which may explain this result. However, upon treatment with sodium napthalenide lactone 7 was fully 
converted but all attempts to isolate and purify the deprotected amine 9 were unsuccessful. Therefore, the detosylated amine was reprotected in situ with $\mathrm{Boc}_{2} \mathrm{O}$ to provide 8 in $15 \%$ yield, anticipating a clean cleavage of the Boc group to circumvent subsequent purification of the free amine. Indeed, Boc removal in the presence of TFA in dichloromethane (DCM) was successful and provided, after purification by preparative TLC, the volatile derivative 9 in $34 \%(6.5 \mathrm{mg})$ yield. Although this material contained some impurities (see Supporting Information File 1 for copies of ${ }^{1} \mathrm{H}$ and ${ }^{13} \mathrm{C}$ spectra), it was of sufficient purity for preliminary pharmacological evaluations.

However, since our aim was to develop a strategy for the late stage $\mathrm{N}$-functionalization applicable for a medicinal chemistry
SAR approach, the route described above was unsatisfactory. Therefore we turned our attention to an alternative protecting group, namely the $\mathrm{Cbz}$ group (see Scheme 2). We envisioned that the reductive removal of this protective group would allow for an easier isolation of the volatile final product. Unfortunately, an alkylation of the Cbz-protected propargylamine $\mathbf{1 0}$ was unsuccessful. To circumvent this issue an initial protection of the amine 10 using $o-\mathrm{NsCl}$ (o-nosyl chloride) led to nosyl derivative 11 in $98 \%$ yield. The subsequent alkylation of $\mathbf{1 1}$ with homoallyl bromide provided the $o$-Ns-protected derivative $\mathbf{1 2}$ in 97\% yield. A straightforward deprotection-reprotection procedure then furnished the Cbz-protected species $\mathbf{1 3}$ in $96 \%$ yield. Unfortunately, the attempted functionalization by treatment with $n$-BuLi and quenching with ethyl chloroformate led to a
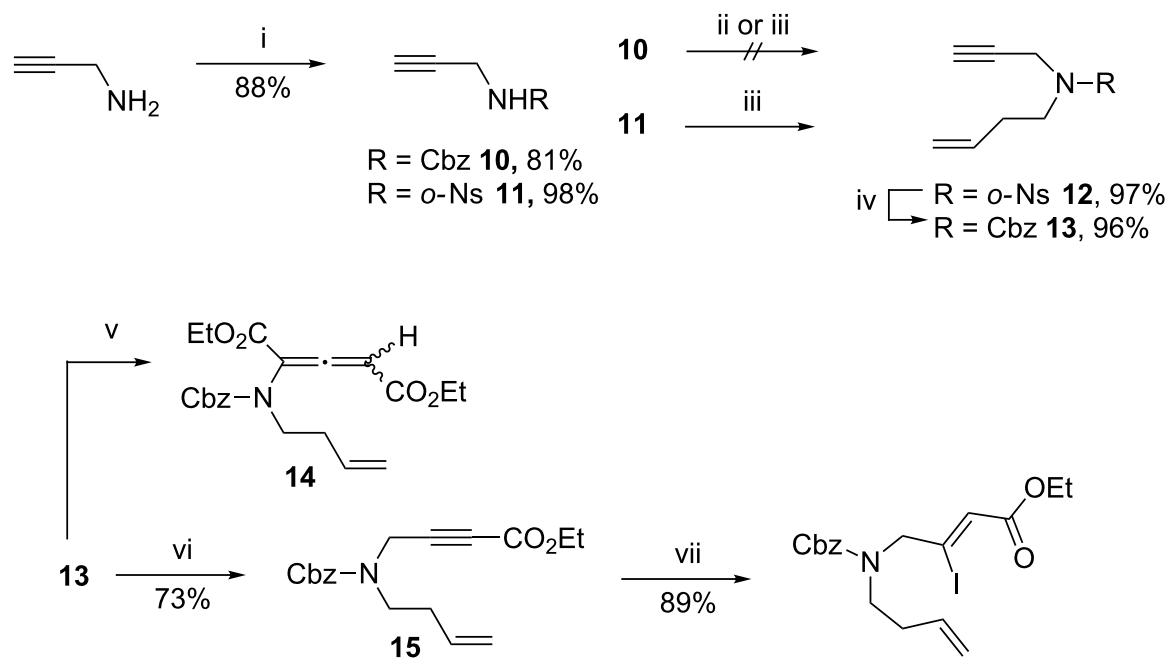

(Z) -16

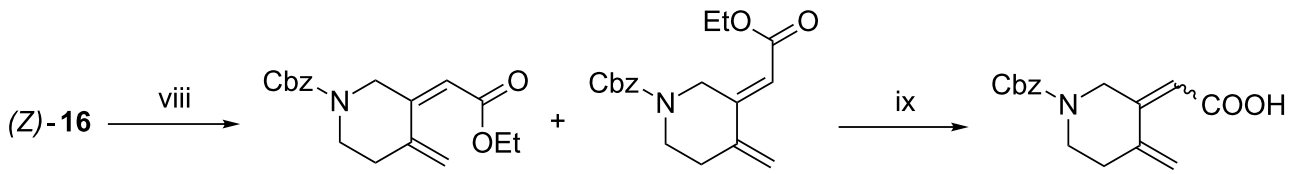

(E)-17

(Z)-17

$18+19$

$18+19$

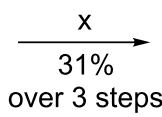

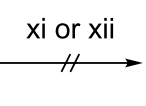

20

$\mathrm{Cbz}$

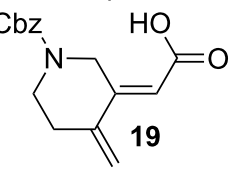<smiles>O=C1CC2=C(CCNC2)CO1</smiles>

9

not isolated

Scheme 2: First strategy towards the $\mathrm{CD}$ fragment (Cbz-strategy). i) R-Cl, $\mathrm{TEA}, \mathrm{CH}_{2} \mathrm{Cl}_{2}, 0{ }^{\circ} \mathrm{C}$. ii) $\mathrm{NaH}, \mathrm{DMF}, 0{ }^{\circ} \mathrm{C}$, then 3-buten-1-yl methanesulfonate, $100{ }^{\circ} \mathrm{C}$. iii) 4-Bromobut-1-ene, $\mathrm{K}_{2} \mathrm{CO}_{3}$, DMF, $60{ }^{\circ} \mathrm{C}$. iv) a) $p-\mathrm{MePhSH}$, aq $\mathrm{NaOH}, \mathrm{CH}_{3} \mathrm{CN}, 50{ }^{\circ} \mathrm{C}$; b) $\mathrm{CbzCl}$, TEA, DCM, $0{ }^{\circ} \mathrm{C}$ to rt. v) $\mathrm{LiHMDS}$, THF, $-78{ }^{\circ} \mathrm{C}, 1 \mathrm{~h}$, then $\mathrm{ClCO}_{2} \mathrm{Et},-78^{\circ} \mathrm{C}$ to rt. vi) LiHMDS, THF, $-78{ }^{\circ} \mathrm{C}, 2 \mathrm{~h}$, then $\mathrm{ClCO}_{2} \mathrm{Et},-78{ }^{\circ} \mathrm{C}, 1 \mathrm{~h}$. vii) $\mathrm{Lil}, \mathrm{AcOH}^{\circ}, 70{ }^{\circ} \mathrm{C}$. viii) $\mathrm{PdCl}\left(\mathrm{PPh}_{3}\right)_{2}$, $\mathrm{Ag}_{2} \mathrm{CO}_{3}, \mathrm{THF}, 60^{\circ} \mathrm{C}$. ix) $\mathrm{LiOH}, \mathrm{H}_{2} \mathrm{O}$, THF, rt. x) BHT (cat.), PhMe, reflux. xi) Pd/C, $\mathrm{H}_{2}$, EtOAc or MeOH or $\left.\mathrm{AcOH} . \mathrm{xii}\right) \mathrm{Pd}(\mathrm{OH})_{2}, \mathrm{H}_{2}, \mathrm{EtOAc}$ or $\mathrm{MeOH}$ or $\mathrm{AcOH}$. 
complex mixture of products; the same trend was also observed when switching to LDA as the base. When LiHMDS was applied in this reaction a double addition of ethyl formate took place giving rise to allenamide $\mathbf{1 4}$ as the major product [21] After extensive optimization, the optimal results were obtained by treatment of 13 with 1 equiv of LiHMDS at $-78{ }^{\circ} \mathrm{C}$ for $2 \mathrm{~h}$ before the addition of 5 equiv of ethyl chloroformate. The resulting mixture was then left at $-78^{\circ} \mathrm{C}$ for $1 \mathrm{~h}$ before quenching at low temperature, which proved vital to avoid the allenamide formation. The careful control of the reaction conditions in this way provided the desired product $\mathbf{1 5}$ in $73 \%$ yield and the subsequent $Z$-stereoselective addition of LiI proceeded without problems to give $(Z)-\mathbf{1 6}$ in $89 \%$ yield. Unfortunately, performing the intramolecular Mizoroki-Heck cyclization at room temperature using the optimized reaction conditions described above, led to the formation of byproducts. However, carrying out the cross-coupling reaction at $60{ }^{\circ} \mathrm{C}$ afforded the desired product $(E)-\mathbf{1 7}$ along with byproduct $(Z)-\mathbf{1 7}$ (which was believed to be the (Z)-6-exo isomer). Hydrolysis of this mixture was achieved with $\mathrm{LiOH}$ giving carboxylic acids 18 and 19 and running the reaction at a $0.01-0.02$ molar scale was important for it to go to completion overnight. Higher concentrations of the starting material seemed to slow down the reaction, which also caused hydrolysis of the $\mathrm{Cbz}$ group to some extent.

The final ring-closure to the CD-ring fragment $\mathbf{2 0}$ was successfully achieved with $31 \%$ yield over 3 steps. Only the desired (E)-6-exo 18 isomer reacted, leaving the (Z)-exo isomer 19 uncyclized, as anticipated. Inspired by the successful $\mathrm{Cbz}$ deprotection of a very similar system [22], the final hydrogenolysis of the $\mathrm{Cbz}$ protecting group with $\mathrm{H}_{2}$ and either $\mathrm{Pd} / \mathrm{C}$ or $\mathrm{Pd}(\mathrm{OH})_{2}$ (up to $50 \mathrm{~mol} \%$ catalyst loading) in EtOAc, $\mathrm{MeOH}$ or $\mathrm{AcOH}$ was attempted, but no trace of the desired lactone 9 was observed. A control experiment with the addition of tosyl chloride after the hydrogenolysis to form the known tosyl-protected intermediate $\mathbf{7}$ indicated no signs of product and therefore the $\mathrm{CBz}$ strategy was also abandoned.

\section{Second strategy without protecting group}

Since the protective group removal was problematic we decided to preinstall the desired $\mathrm{N}$-substituent and thereby avoid any N-protective group (see Scheme 3). The second strategy started with an $\mathrm{N}$-alkylation of the commercially available $N$-methyl propargylamine with homoallyl bromide providing the tertiary amine 21 in $69 \%$ yield which was used without further purification. The subsequent treatment with $n$-BuLi and trapping with ethyl chloroformate provided alkyne 22 in $72 \%$ yield which reacted with $\mathrm{LiI}$ in acetic acid furnishing the desired (Z)-vinyl iodide 23 in $79 \%$ isolated yield. A concise screening of the Mizoroki-Heck reaction conditions (which involved Jeffery conditions [23], $\mathrm{Pd}_{2} \mathrm{dba}_{3} / \mathrm{Xantphos} \mathrm{[24]} \mathrm{or} \mathrm{Fu's} \mathrm{salt} \mathrm{[25],} \mathrm{and}$ $\mathrm{PdCl}_{2}\left(\mathrm{PPh}_{3}\right)_{2}$ in combination with either $\mathrm{K}_{2} \mathrm{CO}_{3}$ or $\left.\mathrm{Ag}_{2} \mathrm{CO}_{3}\right)$ revealed that the optimized conditions from the first strategy still performed quite well for this new approach. Indeed, when using a combination of $\mathrm{PdCl}_{2}\left(\mathrm{PPh}_{3}\right)_{2}$ as catalyst and $\mathrm{Ag}_{2} \mathrm{CO}_{3}$ as base to secure cationic Heck conditions, no trace of the undesired 6-endo product was observed. However, when the reaction mixture was heated at $60{ }^{\circ} \mathrm{C}$ elimination of $\mathrm{HI}$ to form alkyne 22 was observed as the major product and at $25^{\circ} \mathrm{C}$ and $40{ }^{\circ} \mathrm{C}$ conversion was very slow. Interestingly, at $50{ }^{\circ} \mathrm{C}$ the iodide $\mathbf{2 3}$ was selectively converted into the desired (E)-6-exo product 24 in $75 \%$ isolated yield with only $13 \%$ formation of the elimination product $\mathbf{2 2}$, and no trace of the undesired (Z)-6exo product. The subsequent hydrolysis of the ethyl ester $\mathbf{2 4}$ at room temperature smoothly provided carboxylic acid $\mathbf{2 5}$ in $81 \%$ yield with retention of the $E$-configuration, whereas isomerization of the olefin occurred at higher temperatures.

Subjecting 25 to the standard conditions for the final $6 \pi$-electrocyclization (toluene, THF, or DME) at $80-150{ }^{\circ} \mathrm{C}$ either led to no conversion of the starting material or complete decomposition at elevated temperatures. We speculated that the low solubility of carboxylic acid $\mathbf{2 5}$ in these apolar solvents was the reason. However, addition of small amounts of $\mathrm{MeOH}$ in order to increase polarity was detrimental and led to decomposition

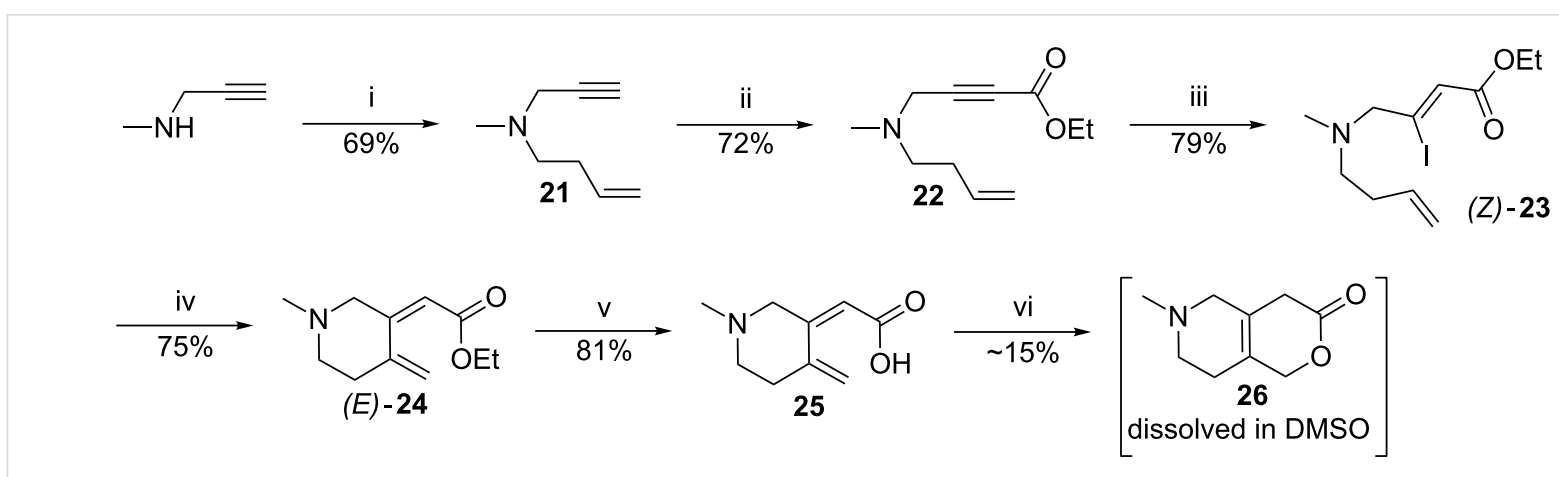

Scheme 3: Second strategy towards the $\mathrm{CD}$ fragment. i) 4-Bromobut-1-ene, $\mathrm{K}_{2} \mathrm{CO}_{3}$, acetone, $70{ }^{\circ} \mathrm{C}$. ii) $n$ - BuLi, $\mathrm{THF},-78^{\circ} \mathrm{C}, 1 \mathrm{~h}$, then $\mathrm{CICO}{ }_{2} \mathrm{Et}$, $-78{ }^{\circ} \mathrm{C}, 1$ h. iii) Lil, $\mathrm{AcOH}, 50^{\circ} \mathrm{C}$. iv) $\mathrm{PdCl}_{2}\left(\mathrm{PPh}_{3}\right)_{2}, \mathrm{Ag}_{2} \mathrm{CO}_{3}$, THF, $50^{\circ} \mathrm{C}$. v) $\mathrm{LiOH}, \mathrm{H}_{2} \mathrm{O}$, THF, rt. vi) HFIP, $80^{\circ} \mathrm{C}$. 
upon heating. Since the desired cyclization could be also approached as an intramolecular Michael addition we attempted to mediate the reaction by applying basic $\left(\mathrm{K}_{2} \mathrm{CO}_{3}, \mathrm{LiOH}\right)$ and acidic ( $\mathrm{TFA}, \mathrm{BF}_{3}$ ) conditions but unfortunately this caused complete decomposition of the starting material upon heating. However, the cyclization was successful by heating 25 at $80^{\circ} \mathrm{C}$ in the slightly acidic hexafluoro-2-propanol (HFIP). HFIP seemed exactly acidic enough to mediate the reaction without causing decomposition. Although $\mathbf{2 5}$ was fully converted into a single product the targeted compound $\mathbf{2 6}$ proved to be extremely difficult to isolate and purify. The compound as the free amine was very volatile and co-evaporated with different solvents (HFIP, MeOH, DCM) and was found to be unstable on silica. Thus, all attempts to purify the material through column chromatography or preparative TLC led to decomposition of the material. Also an attempted isolation of the amine as its hydrochloride or trifluoroacetate failed. Finally, the [6,6]-bicyclic lactone 26 was isolated as a $0.31 \mathrm{mM}$ solution in DMSO after purification by preparative LCMS in a very modest yield of $15 \%$ (see Supporting Information File 1 for more details regarding the preparation of the DMSO solution and the calculation of its concentration for the pharmacological evaluation). Nonetheless, this route provided us with sufficient material to perform a preliminary pharmacological evaluation. Even though the purification of our target molecule proved difficult, the chemistry of the final $6 \pi$-electrocyclization was very effective with full conversion of the precursor 25 into the desired [6,6]bicyclic lactone $\mathbf{2 6}$.

\section{Pharmacological evaluation}

The binding properties of two synthesized CD fragments (compounds 9 and 26) were characterized in a $\left[{ }^{3} \mathrm{H}\right]$-epibatidine binding assay using membranes from HEK293 cells stably expressing the rat heteromeric nAChR subtypes $\alpha 4 \beta 2, \alpha 4 \beta 4$ and $\alpha 3 \beta 4$ as previously described $[10,26]$. The pharmacological evaluation of the $\mathrm{CD}$ fragments revealed that the absence of the methoxy group in the A ring was detrimental to the affinity for the $\alpha 4 \beta 2$ nAChR subtype as depicted in Figure 2 (see Supporting Information File 1 for assay details). This contrasts our recent results obtained for the $\mathrm{AB}$ fragments which retained the affinity comparable to the parent natural product (DH $\beta E$ ), and indicates that the Balle's pharmacophore model is the best description of the key binding interactions of $\mathrm{DH} \beta \mathrm{E}$ to $\alpha 4 \beta 2$, provided that the $A B$ and $C D$ fragments bind similar to $D H \beta E$ in the active site. This is further supported by Wildeboer's study from 2005 who reported a much lower affinity of desmethoxy$\beta$ E compared to the parent DH $\beta E$ [27].

\section{Conclusion}

In summary, we have successfully developed a strategy to construct the CD ring system of DH $\beta E$ and to efficiently access

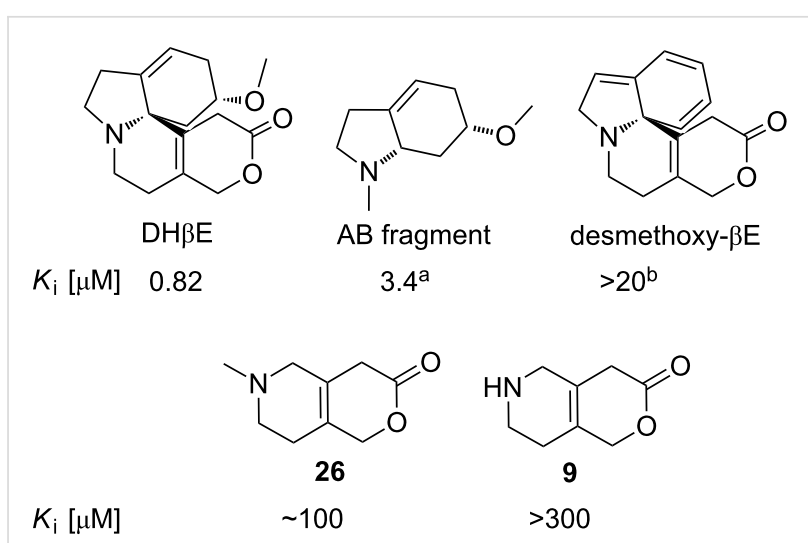

Figure 2: The binding affinities of compounds 9 and 26 at the rat $\alpha 4 \beta 2$ $n A C h R$. a) The $A B$ fragment was evaluated in a $\left[{ }^{3} \mathrm{H}\right]$-epibatidine binding assay [3]. b) Desmethoxy- $\beta E$ was evaluated by Wildeboer in a $\left[{ }^{3} \mathrm{H}\right]$-cytisine binding assay [27].

the synthetically challenging [6,6]-bicyclic lactone fragment in general through an expedient regio- and stereoselective Mizoroki-Heck cyclization approach. This method enabled the synthesis of the elusive and volatile CD fragments ([6,6]bicyclic lactones 9 and 26) of the Erythrina alkaloid DH $\beta$ E. This allowed the investigation of their pharmacological effects lacking the $\mathrm{AB}$ ring substructure present in the parent natural product. Even though the CD fragment proved exceedingly difficult to handle and to purify our results indicate that the absence of the methoxy group on the A ring is detrimental to the affinity. Further studies concerning the construction of new designed [6,6]-bicyclic lactones and the deconstruction of the $\mathrm{DH} \beta \mathrm{E}$ scaffold are currently underway in our laboratory.

\section{Supporting Information}

\section{Supporting Information File 1}

Full experimental details, synthetic procedures, optimization study, failed strategies and pharmacological characterization of the compounds.

[http://www.beilstein-journals.org/bjoc/content/ supplementary/1860-5397-13-98-S1.pdf]

\section{Supporting Information File 2 \\ Copies of NMR spectra. \\ [http://www.beilstein-journals.org/bjoc/content/ supplementary/1860-5397-13-98-S2.pdf]}

\section{Acknowledgements}

The Novo Nordisk Foundation, the Lundbeck Foundation, Jeppe Juhls Mindelegat and the Danish Council for Independent Research - Medical Sciences are gratefully acknowledged for the financial support. 


\section{References}

1. Arneric, S. P.; Holladay, M.; Williams, M. Biochem. Pharmacol. 2007, 74, 1092-1101. doi:10.1016/j.bcp.2007.06.033

2. Reimann, E. Synthesis Pathways to Erythrina Alkaloids and Erythrina Type Compounds. Progress in the Chemistry of Organic Natural Products; Progress in the Chemistry of Organic Natural Products, Vol. 88; Springer: New York, 2007; pp 1-62. doi:10.1007/978-3-211-49389-2_1

3. Jepsen, T. H.; Jensen, A. A.; Lund, M. H.; Glibstrup, E.; Kristensen, J. L. ACS Med. Chem. Lett. 2014, 5, 766-770. doi: $10.1021 / \mathrm{ml} 500094 \mathrm{c}$

4. Weinstock, J.; Boekelheide, V. J. Am. Chem. Soc. 1953, 75, 2546-2550. doi:10.1021/ja01107a003

5. Boekelheide, V.; Agnello, E. J. Am. Chem. Soc. 1951, 73, 2286-2289. doi:10.1021/ja01149a108

6. Hider, R. C.; Walkinshaw, M. D.; Saenger, W. Eur. J. Med. Chem. 1986, 21, 231-234.

7. Megirian, D.; Leary, D. E.; Slater, I. H. J. Pharmacol. Exp. Ther. 1955, 113, 212-227.

8. Shahsavar, A.; Kastrup, J. S.; Nielsen, E. Ø.; Kristensen, J. L.; Gajhede, M.; Balle, T. PLoS One 2012, 7, e40757. doi:10.1371/journal.pone.0040757

9. Iturriaga-Vásquez, P.; Carbone, A.; García-Beltrán, O.; Livingstone, P. D.; Biggin, P. C.; Cassels, B. K.; Wonnacott, S.; Zapata-Torres, G.; Bermudez, I. Mol. Pharmacol. 2010, 78, 366-375. doi:10.1124/mol.110.065490

10. Crestey, F.; Jensen, A. A.; Borch, M.; Andreasen, J. T.; Andersen, J.; Balle, T.; Kristensen, J. L. J. Med. Chem. 2013, 56, 9673-9682. doi:10.1021/jm4013592

11. Tsuda, Y.; Sano, T. The Alkaloids: Chemistry and Pharmacology; Academic Press: San Diego, 1996; Vol. 48, pp 249-337.

12. Tsuda, Y.; Hosoi, S.; Mohri, K.; Isobe, K. Chem. Pharm. Bull. 1992, 40, 2686-2690. doi:10.1248/cpb.40.2686

13. He, Y.; Funk, R. L. Org. Lett. 2006, 8, 3689-3692. doi:10.1021/ol061267r

14. Funk, R. L.; Belmar, J. Tetrahedron Lett. 2012, 53, 176-178. doi:10.1016/j.tetlet.2011.10.161

15. Kawasaki, T.; Onoda, N.; Watanabe, H.; Kitahara, T. Tetrahedron Lett. 2001, 42, 8003-8006. doi:10.1016/S0040-4039(01)01650-1

16. Fukumoto, H.; Takahashi, K.; Ishihara, J.; Hatakeyama, S. Angew. Chem., Int. Ed. 2006, 45, 2731-2734. doi:10.1002/anie.200600210

17. Romero, D. L.; Manninen, P. R.; Han, F.; Romero, A. G. J. Org. Chem. 1999, 64, 4980-4984. doi:10.1021/jo990278d

18. Jepsen, T. H.; Larsen, M.; Jørgensen, M.; Nielsen, M. B. Synlett 2012, 418-422. doi:10.1055/s-0031-1290317

19. Wang, Z.; Lin, X.; Luck, R. L.; Gibbons, G.; Fang, S. Tetrahedron 2009, 65, 2643-2648. doi:10.1016/j.tet.2009.01.065

20. Szostak, M.; Spain, M.; Procter, D. J. J. Am. Chem. Soc. 2014, 136, 8459-8466. doi:10.1021/ja503494b

21. Paul, A.; Einsiedel, J.; Waibel, R.; Heinemann, F. W.; Meyer, K.; Gmeiner, P. Tetrahedron 2009, 65, 6156-6168. doi:10.1016/j.tet.2009.05.045

22. Macdonald, S. J. F.; Montana, J. G.; Buckley, D. M.; Dowle, M. D. Synlett 1998, 1378-1380. doi:10.1055/s-1998-1966

23. Jeffery, T. Tetrahedron 1996, 52, 10113-10130. doi:10.1016/0040-4020(96)00547-9

24. Barder, T. E.; Walker, S. D.; Martinelli, J. R.; Buchwald, S. L. J. Am. Chem. Soc. 2005, 127, 4685-4696. doi:10.1021/ja042491j
25. Littke, A. F.; Dai, C.; Fu, G. C. J. Am. Chem. Soc. 2000, 122, 4020-4028. doi:10.1021/ja0002058

26. Jensen, A. A.; Mikkelsen, I.; Frølund, B.; Bräuner-Osborne, H.; Falch, E.; Krogsgaard-Larsen, P. Mol. Pharmacol. 2003, 64, 865-875. doi:10.1124/mol.64.4.865

27. Wildeboer, K. M. Structure activity relationships of nicotine analogs and Erythrina alkaloids on the alpha 4 beta 2 nicotinic acetylcholine receptor. Ph.D. Thesis, University of Florida, USA, 2005.

\section{License and Terms}

This is an Open Access article under the terms of the Creative Commons Attribution License

(http://creativecommons.org/licenses/by/4.0), which permits unrestricted use, distribution, and reproduction in any medium, provided the original work is properly cited.

The license is subject to the Beilstein Journal of Organic Chemistry terms and conditions: (http://www.beilstein-journals.org/bjoc)

The definitive version of this article is the electronic one which can be found at: doi: $10.3762 /$ bjoc. 13.98 